\title{
Utilization of Peatlands Based on Local Wisdom and Community Welfare in Riau Province, Indonesia
}

\author{
Almasdi Syahza $^{1 *}$, Suwondo $^{2}$, Djaimi Bakce $^{3}$, Besri Nasrul $^{3}$, Riyadi Mustofa ${ }^{4}$ \\ ${ }^{1}$ Institute of Research and Community Services (LPPM), Riau University, Pekanbaru 28293, Indonesia \\ ${ }^{2}$ Biology Education Program, Riau University, Pekanbaru 28293, Indonesia \\ ${ }^{3}$ Faculty of Agriculture, Riau University, Pekanbaru 28293, Indonesia \\ ${ }^{4}$ Center for Environmental Studies, Riau University, Pekanbaru 28293, Indonesia
}

Corresponding Author Email: almasdi.syahza@ @ecturer.unri.ac.id

https://doi.org/10.18280/ijsdp.150716

Received: 29 July 2020

Accepted: 2 October 2020

\section{Keywords:}

multiplier effect, wetland, major

commodities, peatland management

\begin{abstract}
The majority of regions in Riau Province are coastal areas and many communities live on land that is dominated by peat. Peat ecosystems have unique characteristics, as they are classified as wetland areas, while also possessing regions of terrestrial land. Poor maintenance of these ecosystems can cause a variety of issues such as forest fires, drought, flooding, biodiversity loss, increasing emissions, climate change, and social community changes. The purpose of this paper is to formulate a model of peatland utilization based on local wisdom and community welfare, in an effort to support the sustainable management of peat ecosystems in Riau Province. The main commodities of the coastal community are agriculture, coconut, rubber, oil palm, sago, coffee, cocoa, areca nut. Therefore, an understanding of the use of peatlands is needed. This is to prevent damage to the peatland ecosystem, maintain biodiversity, store carbon, produce oxygen, and manage water. Policies and strategies for managing the peat ecosystem are carried out through the development of socio-economic and community culture to realize people's welfare based on local wisdom. The management and use of peatlands have contributed to the economy, even as the main source of livelihood for coastal communities. Utilization of peatlands based on local wisdom can maintain a sustainable peat ecosystem.
\end{abstract}

\section{INTRODUCTION}

Based on global wetland data tahun 2019, Indonesia has the second largest peatland ecosystem in the world, with an area of 22.5 million hectares (ha). The province with the largest area is Papua, with an area covering 6.3 million ha. This is followed by Central Kalimantan (2.7 million ha), Riau (2.2 million ha), West Kalimantan (1.8 million ha) and South Sumatra (1.7 million ha). Furthermore, West Papua has 1.3 million ha of peatland, East Kalimantan has 0.9 million ha and North Kalimantan, North Sumatra and South Kalimantan possess 0.6 million ha each [1].

Peat ecosystems have unique characteristics because they are part wetland and part terrestrial. They also provide complex ecological functions, for example harboring natural resources such as germplasm and wood commodities, providing habitats for fish, and as a carbon storehouse that acts as a climate counterweight. Law Number 32 of 2009, concerning environmental protection and management, states that peat ecosystems are an important part of the environment and that they need to be protected and properly managed. Another study was conducted by Sutikno et al., [2] explain that peatlands are fragile ecosystems formed over thousands of years by the accumulation of dense, wet plant material. State that not only do they offer a direct life support function by providing areas for agricultural purposes, but they also provide benefits such as flooding and global climate control [3]. Furthermore, state that Indonesia's peat swamp forest provides significant benefits on both a local and a global scale. For some local communities, especially for small farmers, these ecosystems offer a significant source of income and many sustainable livelihood options [4].

The ecological function of peatlands in maintaining biodiversity and environmental balance is influenced by the ecosystem's characteristics. Areas of peat are characterized by an acidic $\mathrm{pH}$, poor nutrients, thick organic material and regions that are permanently submerged by water. This means that these ecosystems have a unique biodiversity and only support the existence of certain flora and fauna. Although peatlands provide many benefits, poor management can lead to problems such as forest fires, drought, flooding, subsidence, sea water intrusion, coastal aberration, impacts on social society, loss of biodiversity, increasing emissions and climate change.

Peat ecosystem management is a systematic effort undertaken to preserve the function of peat ecosystems and prevent ecological damage. Strategies include planning, utilization, control, maintenance, supervision, and law enforcement. Planning is an important component of protection and management. The results of research by Uda et al., [5] state that a lack of discussion about the regulations and methods of peatland management is an important cause of non-compliance with regulations, exacerbated by a lack of field monitoring and law enforcement. Research related to peatland management has been widely carried out and includes studies such as Dommain et al., [6] peatlands have been recognized as carbon sinks that are globally important in 
a long period of time which results in a global cooling effect on climate. However, little is known about the role of tropical peatlands in the global carbon cycle. Carbon storage and release levels in Indonesian peatlands in Kalimantan and Sumatra, the largest global concentration of tropical peatlands. The restoration of degraded peatlands start reforestation. The channel blocking strategy is a potential means to achieve this. Changes in peatland topography caused by drainage need to be better understood to further refine the hydrological restoration strategy of degraded peatlands in Indonesia. Within peat ecosystems, many community activities are carried out, especially those that are related to the social economy [7]. Regarding land conservation and management, research that has been carried out includes studies by Syahza and Asmit [8], the development of palm oil plantations results in land conversion, posing potential erosion. In anticipating environmental damage, the Government of Indonesia imposes the Indonesian Sustainable Palm Oil (ISPO) policy. Related research has also been carried out by researchers [9-12].

Peat ecosystem management strategies require several components to ensure success. Firstly, rigorous planning is needed at a national level and at a district level. Maintenance and the protection of ecosystem functions is another key aspect, along with methods that control and monitor the utilization of peat ecosystems. Additionally, efforts that help mitigate of climate change cannot be overlooked. The management of peat ecosystems is strongly influenced by stakeholders, especially in regards to the environmental, social and economic aspects of protected areas. To improve management, stakeholders need to support government steps to improve fire prevention and the destruction of peatland habitats [13]. Peatland management policies and information are urgently needed by the community, these programs must provide policies that guarantee increased income and welfare, and create awareness of the long-term benefits of peatland restoration [14].

The management of the peat ecosystem model is part of the environmental protection and management plan. The diversity of ecological functions, population distribution, distribution of potential natural resources, local culture, community aspirations, climate change, and regional spatial plans are all aspects that need to be considered in peatland management. In terms of local culture (Sanders et al), Land use change is often the result of negotiations between different interests. Often the use of peatlands is based on negotiation practices between communities and owners of capital. Especially for plantation development [15]. Restoration of degraded peatlands usually starts with restoring the water table to wet the surface to control fires and initiating reforestation. Making canal blocks on peatlands is proven to retain moisture and reduce fire prevalence in peatlands [7]. Annual losses of carbon from peat drainage and fires are on average 28 times higher than the predisturbance rate of uptake implying that this carbon reservoir has recently switched from being a net carbon sink to a significant source of atmospheric carbon and is currently in danger of eradication [6]. Management of tropical peatlands as a carbon source reserve [11].

Research related to peatland management has been widely carried out and includes studies [16-18]. Within peat ecosystems, many community activities are carried out, especially those that are related to the social economy. Related research results were carried out [14, 15, 19-23]. Regarding land conservation and management, research that has been carried out include studies [9-12].
The objective of this paper is to formulate a model of peatland utilization based on local wisdom and community welfare, in an effort to support sustainable management of peat ecosystems in coastal areas. In order to achieve these objectives, research that was carried out included the assessment of peat ecosystem functions through an overlay of thematic maps, followed by the delineation of the peat hydrological unit (PHU) map and a map of ecosystem functions. Additionally, the social, economic and cultural conditions of people living in peat ecosystems was analyzed.

\section{RESEARCH METHOD}

Research aiming to support the management of peat ecosystems was carried out through the following stages. Firstly, an inventory of peat ecosystems was created. Next, the ecological functions of peat ecosystems were categorized and, finally, an inventory of local wisdom and community welfare was created. The materials needed for creating peatland utilization models included data on the use of peat ecosystems, the maintenance of ecosystem functions and data on how best to control, monitor and conserve peat habitats. The variables that needed to be considered in the model include diversity of ecological characteristics and functions, distribution of population / socio-economic community, distribution of natural resource potential, local wisdom, community aspirations, climate change and use of superior commodities.

Collected data and information were then analyzed. Three analysis groups needed to be performed in the preparation of the models, namely a function analysis through thematic map overlay and gap analysis, an analysis of the physical and ecological functions, and an analysis of the socioeconomic and cultural conditions of people living in peat ecosystems.

Function analysis through overlay thematic maps: Function analysis was performed by integrating (overlaying) various thematic maps needed to determine the function of peat ecosystems. This included a peatland characteristic map, an ecological function map, a map of peatland distribution, maps of land cover / land utilization, a moratorium map, a surface contour/land relief map, a hydrological network map, a burned area map, a concession area/land utilization permit map, a river flow map, an area administration map, a base map (earth map), a Provincial RTRW map and Regency / City RDTR map and a forest area map (TGHK / Padu Serasi).

Analysis of Peat Land Use and Utilization Analysis: Physical and biological data and information in Riau Province's peat ecosystems were studied using several analyses. This included an analysis of provincial spatial planning and land cover conditions, an analysis of forest area functions and land cover conditions, and an analysis of peat ecosystem functions.

Analysis of Socio-Economic and Cultural Conditions: Socio-economic and cultural analysis of people living on peatlands was perfored by conducting a survey in selected locations. Required information included population density, population distribution according to livelihood, degree of local wisdom and community aspirations. Data and information were obtained from the community using the Rapid Rural Appraisal / RRA approach [24, 25]. A participatory approach was carried out to obtain general information and assessment in the field over a short time period. Information with the RRA method was limited to the data needed in accordance with the research objectives, but was carried out in more depth by 
tracing the information sources, to ensure that complete information was obtained. After data collection, tabulation and descriptive analysis was carried out. Multiplier effect analysis and a health index were conducted in order to determine the contribution of peat ecosystems to the socio-economic community.

From the descriptive analysis results, the peatland utilization model was made based on a matrix or flow diagram. The next stage involved coordination with stakeholders, formulation and a public consultation. Development of the peatland utilization model was carried out through coordination, consultation and discussion with various related institutions, both at provincial and district levels. Academics, non-governmental organizations (LSM), and the community were included to support the study results. The purpose of these activities was to determine the aspirations and goals of various parties in the protection and management of peat ecosystems, based on local wisdom and community welfare.

\section{RESULT}

\subsection{Distribution of peat ecosystems}

Areas of peat (especially the peat dome) play an important role as a reservoir, storing and controlling rainwater and surface flow, therefore minimizing the danger of flooding around areas during the rainy season. The water in the reservoir is then released slowly so that enough is available both for agricultural purposes and other needs during the dry season.

Based on the function of peat areas in one peat hydrological unit, there are peat dome protected areas and peat cultivation areas. Peat dome protected areas is located at the top of the peat dome and covers an area of 2,376,389.24 ha, or $47.80 \%$. This serves to protect the water system in the surrounding area. The Peat Hydrological Units area by district/city in Riau Province is presented in Table 1.

The Peat Hydrological Unit was obtained from the interpretation by Citra Landsat from 2015-2017 and supported by field surveys. The PHU number in Riau Province was 59 regions with 4,971,204.06 ha of land area. In the regency/city area, the PHU number was 43 , in the cross-regency/city area it was 14 and in the cross-provincial region it was 2 . The peat hydrological unit of Riau Province is presented in Figure 1.

Figure 2 presents land cover of peat hydrological unit in Riau Province. Overall secondary swamp forest cover has the largest percentage, at $18.55 \%$ of the total area. Plantation lands and swamp shrub cover $16.65 \%$ and $16.24 \%$ respectively. Protected peat hydrological units areas have been widely used by the community for plantation land, industrial timber plantations, agriculture and ponds. These areas cover $1,040,872.94$ ha $-42.19 \%$ of the total peat hydrological unit. This is something that needs attention in future. As stated by Sanders et al. [15], the use of peatlands is mostly carried out by investors for the benefit of plantation development, especially oil palm. The use of peatlands to become productive land is aimed at the welfare of the surrounding community and a source of state income.

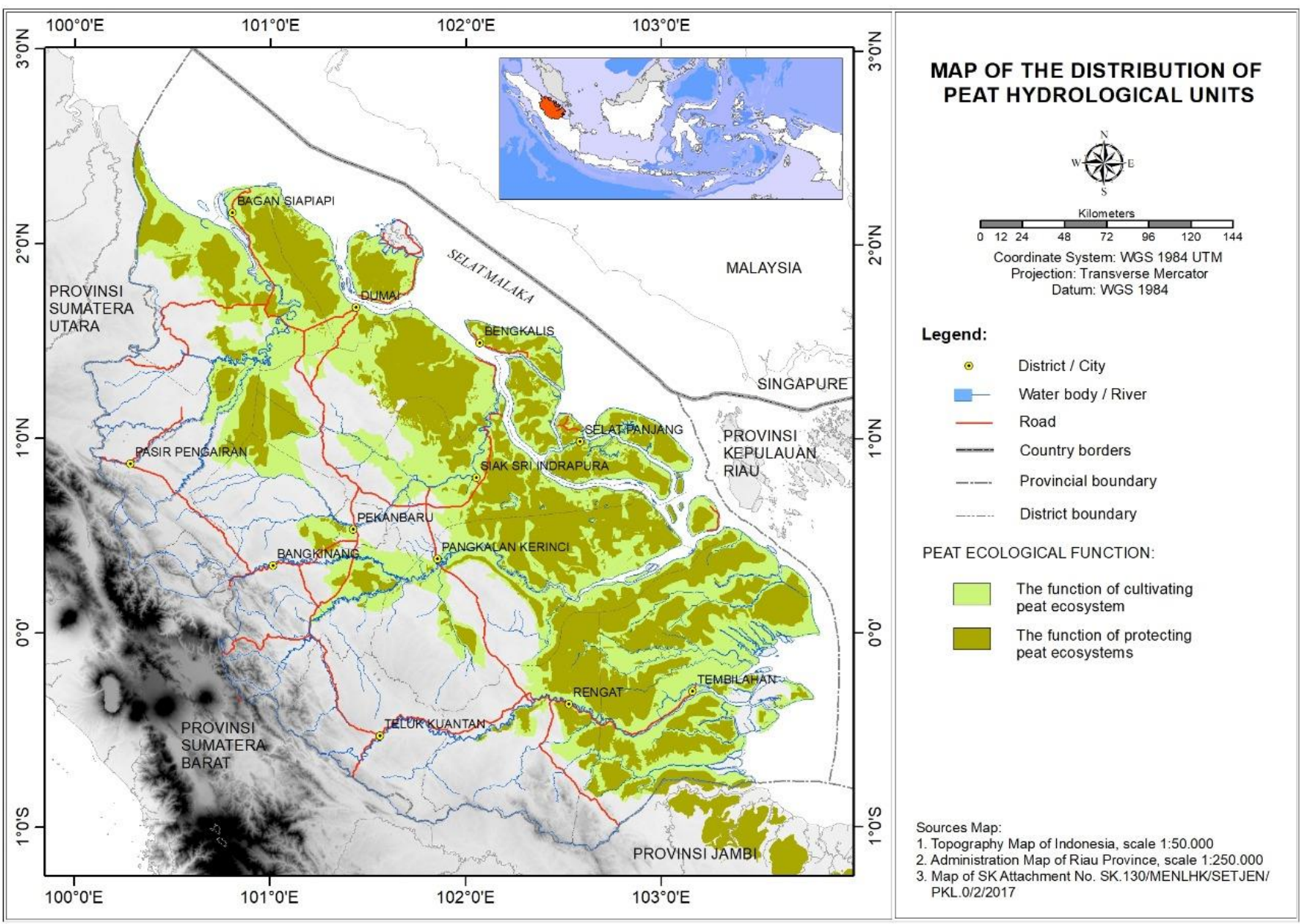

Figure 1. Peat hydrological unit of Riau province 
Table 1. Area of peat hydrological units, peat protected areas, and peat cultivation areas by regency / city

\begin{tabular}{|c|c|c|c|c|c|c|c|}
\hline \multirow{2}{*}{ No. } & \multirow{2}{*}{ Regency } & \multicolumn{2}{|c|}{ Protection Function of Peat Ecosystem } & \multicolumn{2}{|c|}{ Cultivation Functions of Peat Ecosystem } & \multicolumn{2}{|c|}{ Total } \\
\hline & & Area $(\mathrm{Ha})$ & $(\%)$ & Area $(\mathrm{Ha})$ & $(\%)$ & Area $(\mathrm{Ha})$ & $(\%)$ \\
\hline 1 & Bengkalis & $351,278.88$ & 7.07 & $326,003.37$ & 6.56 & $677,282.26$ & 13.62 \\
\hline 2 & Indragiri Hilir & $472,400.80$ & 9.50 & $697,041.69$ & 14.02 & $1,169,442.49$ & 23.52 \\
\hline 3 & Indragiri Hulu & $138,137.19$ & 2,78 & $128,001.48$ & 2.57 & $266,138.67$ & 5.35 \\
\hline 4 & Kampar & $73,968.17$ & 1.49 & $151,866.53$ & 3.05 & $225,834.70$ & 4.54 \\
\hline 5 & Meranti Island & $189,026.61$ & 3.80 & $172,698.41$ & 3.47 & $361,725.03$ & 7.28 \\
\hline 6 & Pelalawan & $445,202.03$ & 8.96 & $339,654.59$ & 6.83 & $784,856.62$ & 15.79 \\
\hline 7 & Rokan Hilir & $266,734.55$ & 5.37 & $357,240.60$ & 7.19 & $623,975.16$ & 12.55 \\
\hline 8 & Rokan Hulu & $49,749.07$ & 1.00 & $68,387.40$ & 1.38 & $118.136,47$ & 2.38 \\
\hline 9 & Siak & $286,250.25$ & 5.76 & $268,144.54$ & 5.39 & $554,394.79$ & 11.15 \\
\hline 10 & DumaiCity & $101,714.10$ & 2.05 & $79,678.67$ & 1.60 & $181,392.77$ & 3.65 \\
\hline \multirow[t]{2}{*}{11} & Pekanbaru City & $1,927.59$ & 0.04 & $6,097.53$ & 0.12 & $8,025.12$ & 0.16 \\
\hline & Total of Riau & $2<376,389.24$ & 47.80 & $2,594,814.82$ & 52.20 & $4,971,204.06$ & 100.00 \\
\hline
\end{tabular}

Source: Apendixes of SK No. SK.130/MENLHK/SETJEN/PKL.0/2/2017 is analyzed

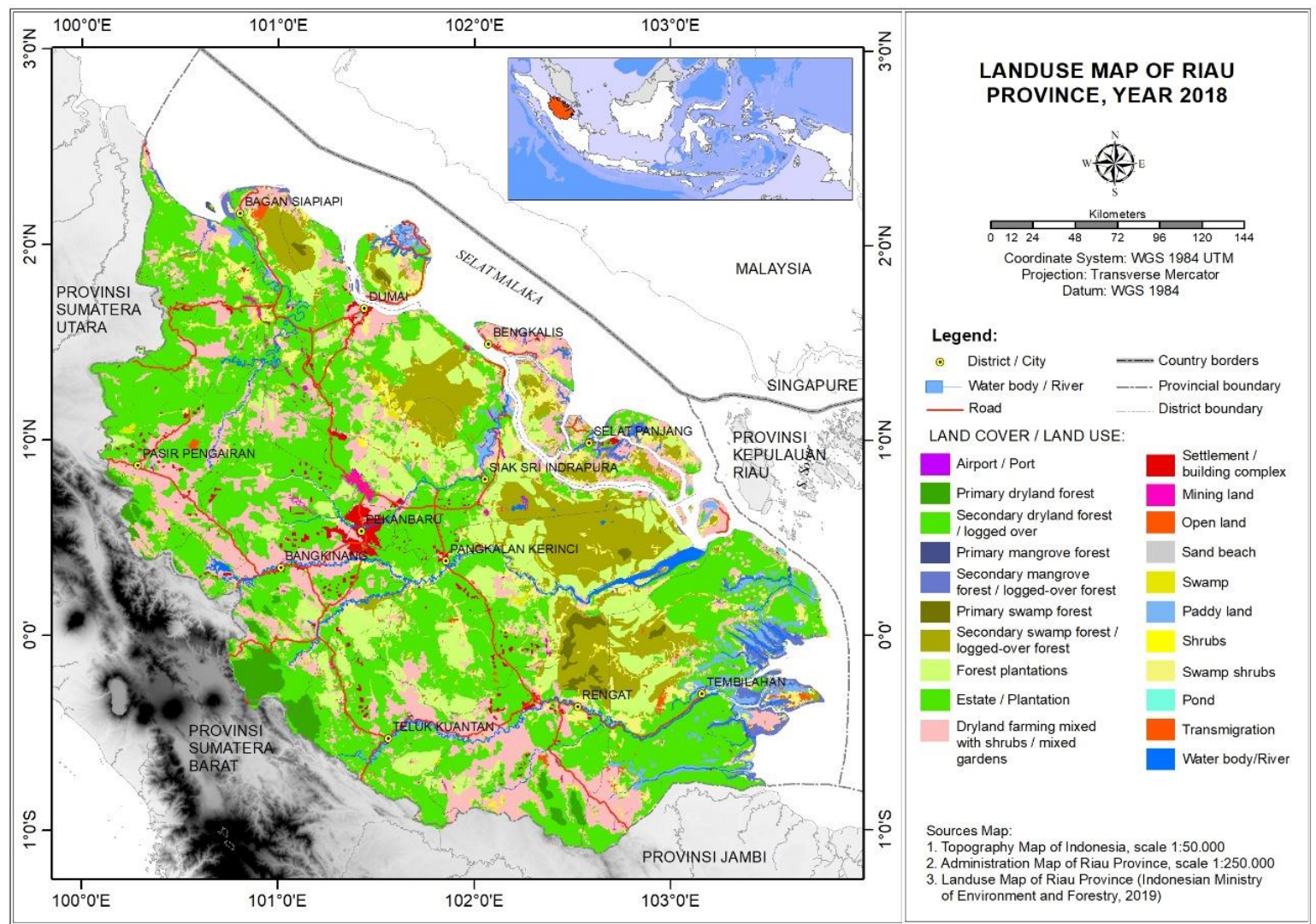

Figure 2. Peat hydrological unit land cover of Riau province

\subsection{Peatland utilization}

Considering the importance of peatlands to Riau Province, both economically and ecologically, their management and utilization need to be carried out carefully, in a way that optimizes community benefits while maintaining ecological functions. Sustainable management will provide many benefits to community welfare in Riau and at a national level, as well as supporting international interests in sustainable development. Peatland management outside the peat dome area is carried out with the aim of water management and habitat restoration. Baqiroh [26] states that the government gave obligations to all permit holders (industrial forest concessions and plantations) to secure the peat dome peak, permitting the utilization of areas outside the peat dome area as long as water management is maintained. Policymakers must carry out long-term monitoring, such as rewetting, revegetation, and revitalization programs for Indonesian peatlands, which will ultimately contribute to sustainable livelihoods for local communities and reduce impacts on regional climate [16].

The peat area in Riau Province is used by various groups, such as individuals in the community and companies doing business in forestry and related sectors. The community uses peatlands as plantations, for agriculture, for housing and for traditional business activities. Companies use the area for forestry businesses, both forest entrepreneur rights and industrial forest, and also for plantations. From the results of the peat hydrological unit map overlay with Provincial Spatial Planning (RTRWP), the area of protected forest covers $2,376,389.24$ ha and the cultivation area covers $2,594,814.82$ ha. The peat hydrological unit region spatial plan of Riau Province is presented in detail in Table 2. In line with the results of the study, Uda et al., [27] showed that most of Indonesia's peatlands have been converted for agricultural and plantation purposes. These areas have the potential to become 
affected by droughts and forest fires, therefore increasing the risk of releasing more $\mathrm{CO}_{2}$ emissions into the atmosphere. The sustainable use of peat ecosystems contributes to the income of local communities. For example, the welfare index in rural areas has increased through community-based plantation development [28].

Table 2. Function of spatial planning peat hydrological unit at Riau province

\begin{tabular}{cccc}
\hline \multirow{2}{*}{ No } & \multirow{2}{*}{ RTRWP Function } & \multicolumn{2}{c}{ Peat Ecosystem Function(ha) } \\
& Protection & Cultivation \\
\hline 1 & Water area & 125.00 & $17,723.19$ \\
2 & Directions for Other Use & $616,017.22$ & $1,135,926.30$ \\
3 & Protected forest & $22,356.39$ & 123.20 \\
4 & Production forest & $1,052,527.81$ & $714,143.00$ \\
5 & Conversion Production Forest & $239,936.07$ & $431,154.28$ \\
6 & Limited production forest & $212,487.89$ & $293,068.67$ \\
7 & Nature Reserve Area or & $232,938.86$ & $2,676.19$ \\
& Nature conservation area & $2,376,389.24$ & $2,594,814.82$ \\
\hline
\end{tabular}

Source: Appendix of SK No. SK.130/MENLHK/SETJEN/PKL.0/2/2017 is analyzed

\subsection{Peat ecological function}

One of the vital functions of peat swamps is their ability to store $\mathrm{CO}_{2}$ in large quantities. However, this $\mathrm{CO}_{2}$ is released during reclamation, drainage or burning. Rising levels of $\mathrm{CO}_{2}$ in the air adds to the greenhouse effect and causes a gradual increase in air temperature, which has a negative impact on the Earth's climate system. According to Surahman et al, exploitation of Indonesian peatlands combined with improper management has created vast areas of degraded peat ecosystems. These regions have become a key source of $\mathrm{CO}_{2}$ emissions through peat decomposition. On the other hand, proper use of peat habitats for food production is likely to play an important part in the future due to increased food demand and inadequate land availability for agrarian development on mineral soils [29]. Constructed wetlands (CWs) have been increasingly developed worldwide for the treatment of rainwater and wastewater. In this context, CWs have been seen as an economically attractive, energy-efficient way to provide high standard wastewater treatment [30].

Peat ecosystems provide various ecological functions, both directly and indirectly. Direct functions include fisheries, transportation and forest resources. Indirect functions include hydrological regulation, providing habitats which increase biodiversity and climate stabilization. Furthermore, Fujita et al., [31] showed that natural peat swamp forests have an irreplaceable value for biodiversity conservation. In comparison, poorly maintained rubber plantations provide low-quality habitats for forest-dependent species and offer very little support to bird diversity. Built and natural wetlands have been used successfully in the treatment and polishing of municipal wastewater throughout the world. Natural wetlands are able to reduce quite a lot of heavy metals in city dumps during their trips to the wetlands. This can make water downstream of wetlands safe for rural communities to use water for irrigation purposes [32].

Peat ecosystems have a great potential for hydrological regulation. They function as catchment areas for water during floods and then release this water gradually during the dry season. Therefore, peatlands provide an important water source for agricultural activities, while also preventing salt water intrusions. For local people, peat swamp forests are unique places that play important roles in their lives. In rural areas, for example, peat habitats provide easy access to freshwater sources which are used for everyday needs and agricultural irrigation. With aims of supporting ecosystem restoration, results from Budiman et al., [33] indicate that revegetation of peat habitats often produces ineffective results. Furthermore, there are trade-offs between restoration methods and the need to provide short-term economic benefits for local communities through horticultural practices, therefore strategies that try to combine these two activities are often ineffective.

\subsection{Policies and strategies for socio-economic and local wisdom development}

Strategies for developing the socio-economic situations of communities aim to improve welfare, especially for people living on peatlands. To do this, there are several targets that need to be achieved. These include increasing life expectancy, decreasing population growth and crude mortality rate, increasing social and cultural resilience, and increasing the position and role of women in the community. Additionally, further targets include increasing the active participation of young people, increasing cultural and sporting achievements, improving the local economy, education levels and health, encouraging better family planning and social welfare, and maintaining a sustainable environment. Based on the results of Connor et al., [34] population changes in a community have an impact on the external environment, with populations in peatland communities being affected by internal and external migration at different rates. Peatlands and wetlands bring together a large number of services and functions, especially ecological and social. Everything depends on the ecological quality of the ecosystem and on the equipment and services that enable it to be enjoyed. Tourism is an economic segment, contributing to coastal regions throughout the world. Therefore, complete management of the wetland environment must include a tourism perspective [35].

The management of social and cultural development policies in peat ecosystems includes a variety of key steps. Firstly, it aims to increase income levels and empower local communities to carry out environmental-based economic activities. It also targets an improvement in the way human and environmental resources support each other, with a paradigm approach to developing the local economy. The development of social resilience is another goal, with aims to increase appreciation for the elderly, to improve people's awareness towards social problems and to increase accessibility for disabled people. Additionally, improving population welfare through policies that take into account the environmental aspects central to development can also help. Finally, another important step is the development and promotion of the national culture. This includes the encouragement of Indonesian cultural values, the development of creativity freedom in the arts and the Indonesian film industry, and the preservation of traditional arts and cultures as a vehicle for tourism development. Tourism development should be conducted with a holistic approach based on community empowerment.

Peat ecosystem management is inseparable from the role of civil society, especially in communities living around peatland areas. Policy strategies for community empowerment should focus on social development among communities that practice cultivation, especially in the plantation and industrial 
plantation subsector. Maintaining local wisdom of peat habitats is also important, along with promoting discussions related to utilizing ecosystems in a way that maintains an environmental balance and sustainable development. In terms of policy strategies, these include transferring agricultural technology that is adaptive to the unique characteristics of peat ecosystems. Furthermore, building a strong farmer institutional system as well as access to local farmers' capital system will also help to achieve management goals, along with developing cultivation systems by improving knowledge of local people and migrants. Hergoualc'h et al revealed, explained that peatland restoration is a potential solution, but one that faces issues arising from conflicts between stakeholders who have differing interests in the land. Successful restoration programs will depend on how these differing interests are reconciled, while also requiring improved governance and an increasing technical capacity based on community interests and sustainable development [4]. Showed that peat conservation incurs high costs, but that native and adaptive plants have the potential to develop further markets, cultivation techniques for paludiculture and management options to restore habitats [36]. Stated that the utilization of tropical peatland forests has contributed to the timber industry, but with a side effect being the massive degradation and deforestation of tropical forest areas. As a result, serious reductions in wood resources and environmental services occur in peat forests, with land managers caught between the needs of timber production, conservation and restoration of environmental services [37].

Peatland utilization by communities in coastal areas has made economic contributions both regionally and nationally. For rural communities living in these ecosystems, land has traditionally been used as a source of income and local wisdom of peat utilization has been maintained for a long time [38]. Peat ecosystems provide habitats for various types of freshwater fish, including those with commercial value, such as cork fish (Chana sp.), Catfish (Clarias sp.), Betok (Anabas testudineus), sepat (Trichogaster sp.), and tambakan (Helostoma sp.). Fishing in these areas has the potential to be a key income source for surrounding communities. Furthermore, rivers flowing on peatlands are also the main means for transportation in the surrounding community.

Research conducted by Syahza [39], stated that the welfare index of rural communities from 2012-2018 showed positive results. For example, during the period of 2012-2014, the welfare index increased by $27 \%$. Likewise, in the periods of 2014-2016 and 2016-2018, the welfare index in rural areas increased by $31 \%$ and $16 \%$ respectively. The impact of agricultural development in rural areas, along with the major commodities of coastal regions, shows that the multiplier effect (ME) index is also positive. In coastal areas, the ME index for sago commodities in wetlands amounted to 2.28. This means that an investment of $\$ 1$ in a sago farm will result in a return in the next period of $\$ 2.28$. Sago commodities therefore provide opportunities for economic development for farmers in coastal areas. In peat ecosystems, the main commodity in Sumatra and Kalimantan is palm oil. Syahza and Asmit [40], stated that the ME index of oil palm farming in 2018 was 1.93 . This means that an investment of $\$ 10$ in palm oil commodities resulted in a return in the next period of $\$ 19.3$. Furthermore, research by Obidzinski et al. [41], showed that investment in palm oil increases economic output in the province, generates employment and increases workers' salaries. This is partly because oil palm businesses operate separately and have limited economic multipliers.

\subsection{Peat land use model}

Peat ecosystem restoration can be carried out through rearranging the hydrological function where the peat dome is used as water storage for the long storage of water. Water system restoration is prioritized in the peat dome area by completely closing it. These activities can take the form of blocking of canals construction. Peatland management programs can be carried out by, among others: 1) Constructing canal blocks in each of the existing canals so that the peatlands around the canals become wet. The construction of canal blocking can involve the local community. These activities can absorb local workers; 2) Revegetation above the bulkhead is expected to strengthen the bulkhead construction. To prevent abrasion on the sides of the canal walls, it is necessary to plant a variety of native peatland endemic plants that have the potential as a source of income for the local community. Highly recommended for activities in the peat protection function zone. Rehabilitation of vegetation on peatlands aims to restore land cover so that the function of the peat ecosystem can be restored to normal.

In the cultivation function zone area (outside the protection function), a variety of peatland farming has been developed, such as specific fruit trees for peatlands, food crops, nontimber forest products including natural rubber, rattan, honey bees and plants that produce energy wood, timber plants an alternative source of fiber. Community involvement in the vegetation rehabilitation process can be developed through local community-based nurseries by developing endemic plants. In addition to developing the community's economy, it is also at the same time educating the local community in increasing environmental awareness on peatlands. Potential commodities that are suitable for development on peatlands include coconut, sago, rubber, oil palm, coffee, cocoa, and areca nut. Particularly for commodity, Sago is a wetland plant that can maintain a balance in peatland areas, indirectly preventing the potential for peatland fires. Syahza et al, sustainable use of peatlands contributes to local community income. The welfare index in rural areas increases through community-based fighting development [38]. Tropical peatland forest has contributed to the timber industry but has led to degradation and deforestation in massive tropical peat swamp forest areas [37].

\section{CONCLUSION}

Peat ecosystems provide many benefits to local communities, for example playing an important role in storing and controlling rainwater and surface flow. This minimizes the danger of flooding during the rainy season. Sustainable management of peatlands will have an impact on overall community welfare. Ecosystem management based on local wisdom and community welfare needs to focus on socioeconomic and cultural development strategies. The overall goal of habitat management is to improve the welfare of people living in peatland areas. Utilization of this ecosystem by communities in coastal areas has made economic contributions both regionally and nationally. This is especially true for rural communities, who use the land as their main source of income. For example, peat areas are used by the community to grow commodities such as oil palm, coconut, 
rubber, sago, coffee, cocoa and areca nut.

Strategies for community empowerment in efforts to protect peat ecosystems include: 1) Promoting social development among communities that practice cultivation, especially in the plantation and industrial plantation subsector; 2) Ensuring that local wisdom is maintained in the community; and 3) Recommend to local and central governments to issue policies related to the use of peatlands in ways that maintain environmental balance and sustainable development based on local wisdom.

In terms of policy strategies, transferring agricultural technology that is adaptive to the unique characteristics of peat ecosystems should be a key target. This needs to be combined with building a strong farmer institutional system, providing access to the local farmers' capital system, and developing cultivation systems by improving knowledge of local people and migrants.

\section{ACKNOWLEDGMENT}

Thanks to the Institute of Research and Community Services (LPPM), Riau University, Ministry of Environment and Forestry that has facilitated research activities in Riau Province, Contract Number SPK-110A/PPK-PKG/07/2016. This paper is also supported by the results of the Higher Education Basic Research (PDUPT) grant for the 2018-2020 fiscal year. Contract number 205 / SP2H / LT / DRPM / 2019.

\section{REFERENCES}

[1] Katadata. (2019). Luas Gambut Indonesia Terbesar Kedua di Dunia. https://katadata.co.id/infografik/2019/04/29/luasgambut-indonesia-terbesar-kedua-di-dunia, accessed on Jun. 18, 2020.

[2] Sutikno, S., Amalia, I.R., Sandhyavitri, A., Syahza, A., Widodo, H., Seto. T.H. (2020). Application of weather modification technology for peatlands fires mitigation in Riau, Indonesia. AIP Conference Proceedings 2227, 030007: 1-9. https://doi.org/10.1063/5.0002137

[3] Syahza, A., Bakce, D., Irianti, M. (2019). Improved peatlands potential for agricultural purposes to support sustainable development in Bengkalis district, Riau province, Indonesia. Journal of Physics: Conference Series, 1351(1). http://doi.org/10.1088/17426596/1351/1/012114

[4] Hergoualc'h, K., Atmadja, S., Carmenta, R., Martius, C., Murdiyarso, D., Purnomo, H. (2018). Managing peatlands in Indonesia challenges and opportunities for local and global communities. Center for International Forestry Research, 205: 1-8. https://doi.org/10.17528/cifor/006449

[5] Uda, S.K., Schouten, G., Hein, L. (2018). The institutional fit of peatland governance in Indonesia. Land Use Policy, 103300. https://doi.org/10.1016/j.landusepol.2018.03.031

[6] Dommain, R., Couwenberg, J., Glaser, P.H., Joosten, H., Suryadiputra, I.N.N. (2014). Carbon storage and release in Indonesia since the last deglaciation. Quaternary Science Reviews, 971: 1-32. https://doi.org/10.1016/j.quascirev.2014.05.002

[7] Ritzema, H., Limin, S., Kusin, K., Jauhiainen, J., Wösten,
H. (2014). Canal blocking strategies for hydrological restoration of degraded tropical peatlands in Central Kalimantan, Indonesia. Catena, 114: 11-20. https://doi.org/10.1016/j.catena.2013.10.009

[8] Syahza, A., Asmit, B. (2020). Development of palm oil sector and future challenge in Riau province, Indonesia. Journal of Science and Technology Policy Management, 11(2): 149-170. https://doi.org/10.1108/JSTPM-072018-0073

[9] Miettinen, J., Liew, S. (2010). Degradation and development of peatlands in Peninsular Malaysia and in the islands of Sumatra and Borneo since 1990. Land Degradation \& Development, 21(3): 285-296. https://doi.org/10.1002/ldr.976

[10] Miettinen, J., Wang, J., Hooijer, A., Liew, S. (2013). Peatland conversion and degradation processes in insular southeast Asia: A case study in Jambi, Indonesia. Land Degradation \& Development, 24(4): 334-341. https://doi.org/10.1002/ldr.1130

[11] Lawson, I.T., Kelly, T.J., Aplin, P., Boom, A., Dargie, G., Draper, F.C.H., Hassan, P.N.Z.B.P., Hoyos-Santillan, J., Kaduk, J., Large, D., Murphy, W., Page, S.E., Roucoux, K.H., Sjögersten, S., Tansey, K., Waldram, M., Wedeux, B.M.M., Wheeler, J. (2015). Improving estimates of tropical peatland area, carbon storage, and greenhouse gas fluxes. Wetlands Ecol Manage, 23: 327-346. https://doi.org/10.1007/s11273-014-9402-2

[12] Mendes, C., Dias, E., Rochefort, L., Azevedo, J. (2020). Regenerative succession of Azorean peatlands after grazing: Vegetation path to self-recovery. Wetlands Ecology and Management, 28: 177-190. https://doi.org/10.1007/s11273-019-09701-3

[13] Pereira, P., Mierauskas, P., Novara, A. (2016). Stakeholders' perceptions about fire impacts on Lithuanian protected areas. Land Degradation \& Development, 27(4): 871-883. https://doi.org/10.1002/ldr.2290

[14] Schaafsma, M., Beukering, P.J.H., Oskolokaite, I. (2017) Combining focus group discussions and choice experiments for economic valuation of peatland restoration: A case study in Central Kalimantan, Indonesia. Ecosystem Services, 27(A): 150-160. https://doi.org/10.1016/j.ecoser.2017.08.012

[15] Sanders, A.J.P., Ford, R.M., Mulyani, L., Prasti H, R.D., Larson, A.M., Jagau, Y., Keenan, R.J. (2019). Unrelenting games: Multiple negotiations and landscape transformations in the tropical peatlands of Central Kalimantan, Indonesia. World Development, 117: 196210. https://doi.org/10.1016/j.worlddev.2019.01.008

[16] Taufik, M., Veldhuizen, A.A., Wösten, J.H.M., Lanen, H.A.J. (2019). Exploration of the importance of physical properties of Indonesian peatland to assess critical groundwater table depths, associated drought and fire hazard. Geoderma, 3471: 160-169. https://doi.org/10.1016/j.geoderma.2019.04.001

[17] Lupascu, M., Varkkey, H., Tortajada, C. (2020). Is flooding considered a threat in the degraded tropical peatland? Science of The Total Environment, 723: 137988. https://doi.org/10.1016/j.scitotenv.2020.137988

[18] Evans, C.D., Williamson, J.M., Kacaribu, F., Irawan, D., Page, S.E. (2019). Rates and spatial variability of peat subsidence in Acacia plantation and forest landscapes in Sumatra, Indonesia. Geoderma, 338: 410-421. https://doi.org/10.1016/j.geoderma.2018.12.028 
[19] Carmenta, R., Zabala, A., Daeli, W., Phelps, J. (2017). Perceptions across scales of governance and the Indonesian peatland fires. Global Environmental Change, 46:

50-59. https://doi.org/10.1016/j.gloenvcha.2017.08.001

[20] Rosa, E., Dallaire, P.L., Nadeau, S., Cloutier, V., Veillette, J., Bellen, S., Larocque. (2018). A graphical approach for documenting peatland hydrodiversity and orienting land management strategies. Hydrological Processes, $32(7)$ : 873-890. https://doi.org/10.1002/hyp.11457

[21] Meehan, F., Tacconi, L., Budiningsih, K. (2019). Are national commitments to reducing emissions from forests effective? Lessons from Indonesian, Forest Policy and Economics, 108 : 101968. https://doi.org/10.1016/j.forpol.2019.101968

[22] Glina, B., Piernik, A., Hulisz, P., Mendyk, L., Tomaszewska, K., Podlaska, M., Bogacz., A., Spychalski, W. (2019). Water or soil-What is the dominant driver controlling the vegetation pattern of degraded shallow mountain peatlands? Land Degradation \& Development, 30(12): 1437-1448. https://doi.org/10.1002/ldr.3329

[23] Qiu, C., Zhu, D., Ciais, P., Guenet, B., Peng, S. (2020). The role of northern peatlands in the global carbon cycle for the 21st century. Global Ecology and Biogeography, 29(5): 956-973. https://doi.org/10.1111/geb.13081

[24] Alam, A., Ihsan, S. (2012). Role of participatory rural appraisal in community development. International Journal of Academic Research in Business and Social Sciences, 2(8): 25-38.

[25] McCracken, J.A., Pretty, J.N., Conway, G.R. (1988). An introduction to rapid rural appraisal for agricultural development. International Inst. for Environment and Development, London, UK.

[26] Baqiroh, N.F.B. (2019). KLHK Perbolehkan Areal di Luar Kubah Gambut dikelola Kembali, Bisnis.com. https://ekonomi.bisnis.com/read/20190520/ 99/924588/, accessed on July 20, 2020.

[27] Uda, S.K., Hein, L., Sumarga, E. (2017). Towards sustainable management of Indonesian tropical peatlands. Wetlands Ecology and Management, 25: 683-701. https://doi.org/10.1007/s11273-017-9544-0

[28] Syahza, A., Bakce, D., Asmit, B. (2018). Increasing the awareness of palm oil plantation replanting through farmers training. Riau Journal of Empowerment, 1(1): 19. https://doi.org/10.31258/raje.1.1.1

[29] Surahman, A., Soni, P., Shivakoti, G.P. (2018). Reducing $\mathrm{CO}_{2}$ emissions and supporting food security in Central Kalimantan, Indonesia, with improved peatland management. Land Use Policy, 72: 325-332. https://doi.org/10.1016/j.landusepol.2017.12.050

[30] Jiménez-López, E.C., López-Ocaña, G., BautistaMargulis, R.G., Castelán-Estrada, M., Guerrero-Peña, A., Hernández-Barajas, J.R., Torres-Balcázar, C.A., De La Cruz-Luna, E., Romellón-Cerino, M.J., Solís-Sílvan, R. (2017). Wastewater treatment by constructed wetlands with Thalia Geniculata and Paspalum Paniculatum in a tropical system of Mexico. International Journal of Sustainable Development and Planning, 12(1): 42-50. https://doi.org/10.2495/SDP-V12-N1-42-50

[31] Fujita, M.S., Samejima, H., Haryadi, D.S., Muhammad, A., Irham, M., Shiodera, S. (2016). Low conservation value of converted habitat for avifauna in tropical peatland on Sumatra, Indonesia. Ecological Research, 31(2): 275-285. https://doi.org/10.1007/s11284-016$1334-2$

[32] Shibambu, C.S., Gumbo, J.R., Gitari, W.M. (2017). Field study on heavy metal removal in a natural wetland receiving municipal sewage discharge. International Journal of Sustainable Development and Planning, 12(1): 1-10. https://doi.org/10.2495/SDP-V12-N1-1-10

[33] Budiman, I., Bastoni, Sari, E.N., Hadi, E.E., Hapsari, R.D. (2020). Progress of paludiculture projects in supporting peatland ecosystem restoration in Indonesia. Global Ecology and Conservation, 23(e01084): 1-17. https://doi.org/10.1016/j.gecco.2020.e01084

[34] Connor, S.E., Colombaroli, D., Confortini, F., Gobet, E., Ilyashuk, B.P., Ilyashuk, E.A., Leeuwen, J.F.N., Lamentowicz, M., Knaap, W.O., Malysheva, E., Marchetto, A., Margalitadze, N., Mazei, Y., Mitchell, E.D., Payne, R.J., Ammann, B. (2017). Long-term population dynamics: Theory and reality in a peatland ecosystem. Journal of Ecology, 106(1): 333-346. https://doi.org/10.1111/1365-2745.12865

[35] Pueyo-Ros, J., Ribas, A., Fraguell, R.M. (2016). Recreational uses and motivations of visitors in seaside wetlands of Costa Brava (Spain). International Journal of Sustainable Development and Planning, 11(3): 385-395. https://doi.org/10.2495/SDP-V11-N3-385-395

[36] Gunawan, H. (2018) Indonesian peatland functions: Initiated peatland restoration and responsible management of peatland for the benefit of local community, case study in Riau and west Kalimantan provinces. Environmental Resources Use and Challenges in Contemporary Southeast Asia. Asia in Transition, 7: 117-138. https://doi.org/10.1007/978-98110-8881-0_6

[37] Saito, H., Koizumi, A., Gaman, S., Yuda, P., Penyang, Shibuya, M. (2016) Tropical peatland forestry: Toward forest restoration and sustainable use of wood resources in degraded peatland. In: Osaki M., Tsuji N. (eds) Tropical Peatland Ecosystems. Springer, Tokyo. https://doi.org/10.1007/978-4-431-55681-7_35

[38] Syahza. A., Bakce, D., Asmit, B. (2018). Natural rubber institutional arrangement in efforts to accelerate rural economic development in the province of Riau. International Journal of Law and Management, 60(5): 1509-1521. https://doi.org/10.1108/IJLMA-10-20170257

[39] Syahza. A. (2019). The potential of environmental impact as a result of the development of palm oil plantation. Management of Environmental Quality: An International Journal, 30(5): 1072-1094 https://doi.org/10.1108/MEQ-11-2018-0190

[40] Syahza. A., Asmit, B. (2019). Regional economic empowerment through oil palm economic institutional development. Management of Environmental Quality: An International Journal, 30(6): 1256-1278 https://doi.org/10.1108/MEQ-02-2018-0036

[41] Obidzinski, K., Dermawan, A., Hadianto, A., (2014). Oil palm plantation investments in Indonesia's forest frontiers: Limited economic multipliers and uncertain benefits for local communities. Environment, Development and Sustainability, 16: 1177-1196. https://doi.org/10.1007/s10668-014-9519-8 